\title{
Optimum biochar preparations enhance phosphorus availability in amended Mollisols of Northeast China
}

\author{
Ying Han ${ }^{1}$, Xiangwei Chen ${ }^{1 *}$, Enheng Wang ${ }^{1}$, and Xiangyou Xia ${ }^{1}$ \\ 'Northeast Forestry University, School of Forestry, 26 Hexing Road, Harbin 150040, China. \\ "Corresponding author (xwchen1966@nefu.edu.cn).
}

Received: 25 September 2018; Accepted: 3 December 2018; doi:10.4067/S0718-58392019000100153

\begin{abstract}
Biochar amendment to soils can improve soil $\mathrm{P}$ availability, but details on the optimum application of biochar to black soils in Northeast China are limited. Three types of biochar were produced at six pyrolysis temperatures (between 200 and $700{ }^{\circ} \mathrm{C}$ ) and then added to black soil samples. P adsorption-desorption isotherms were fitted by the Langmuir model to evaluate the changes in soil $\mathrm{P}$ adsorption-desorption after biochar amendment. Changes in $\mathrm{P}$ adsorption and desorption depended on biochar feedstock type and pyrolysis temperature. When pyrolysis temperature increased up to $400{ }^{\circ} \mathrm{C}, \mathrm{P}$ sorption maximum $\left(\mathrm{Q}_{\mathrm{m}}\right)$ of soybean pod (SP) and soybean straw (SS) biochar-amended soils were enhanced from 855.65 and $428.84 \mathrm{mg} \mathrm{kg}^{-1}$ to 1666.67 and $1547.62 \mathrm{mg} \mathrm{kg}^{-1}$, respectively, while a further increase in the pyrolysis temperature lowered the adsorption capacity. However, P adsorption of corncob (CC) biochar amended soils declined from 1428.57 $\mathrm{mg} \mathrm{kg}^{-1}$ to $556.70 \mathrm{mg} \mathrm{kg}^{-1}$ as pyrolysis temperature increased. Higher P desorption in SP and SS compared with CC indicated that SP and SS biochar produced at higher than $400{ }^{\circ} \mathrm{C}$ pyrolysis temperatures were considered to be the optimum biochar to enhance $\mathrm{P}$ availability in the black soils of Northeast China.
\end{abstract}

Key words: Batch equilibrium method, biochar amendment, black soil, feedstock type, pyrolysis temperature, phosphorus adsorption and desorption.

\section{INTRODUCTION}

As an essential element for plant growth, $\mathrm{P}$ commonly plays a major role in crop production. Plants can acquire $\mathrm{P}$ as phosphate anions $\left(\mathrm{H}_{2} \mathrm{PO}_{4}{ }^{-}\right.$and $\left.\mathrm{HPO}_{4}{ }^{2-}\right)$ from the soil solution (Gul and Whalen, 2016; Debicka et al., 2016). The $\mathrm{P}$ transformation rate between soil solution and soil solids was reported to be highly dependent on phosphate adsorption and desorption. Therefore, $\mathrm{P}$ adsorption and desorption restrict the capacity of supplying soil $\mathrm{P}$, which affects $\mathrm{P}$ uptake and utilization by plants (Shen et al., 2011). A better understanding of $\mathrm{P}$ adsorption and desorption in agricultural systems is critical for improving $\mathrm{P}$ sustainability and increasing crop productivity.

The black soil region of Northeast China is an important food production area and commodity grain base because of the distinctive properties of high nutrient content and good soil structure (Kang et al., 2016). However, long-term and intensive cultivation has led to serious erosion and other types of soil degradation. The amount of applied P fertilizers exceeds crop requirements and consequently induces $\mathrm{P}$ accumulation in the black soils, which limits $\mathrm{P}$ bioavailability due to $\mathrm{P}$ fixation through sorption or precipitation (Debicka et al., 2016). Therefore, various methods have been investigated to improve $\mathrm{P}$ availability in these black soils. Biochar amendment has been widely used to enhance $\mathrm{P}$ availability, and its response varies among different soil types. For example, biochar amendment can successfully improve P availability in brown soil (Guan et al., 2013), silt loam soil, and clay loam soil (Parvage et al., 2013). In addition, biochar addition 
reduces the available P contents in calcareous soil (Chintala et al., 2014). However, biochar amendment has rarely been investigated in the black soils of Northeast China.

Biochar is a product of either thermal pyrolysis or gasification, and it is created by heating C-rich biomass in conditions of limited or no air presence (Dari et al., 2016). Because of the high physical and chemical capacity of biochar, it has been used as a potential soil-amending agent to improve soil $\mathrm{P}$ availability and increasing crop productivity (Debicka et al., 2016). Biochar not only alters $\mathrm{P}$ availability directly through its anion exchange capacity or effects of cation ( $\mathrm{Al}^{3+}$, $\mathrm{Fe}^{3+}$, and $\mathrm{Ca}^{2+}$ ) activity interactions with P (DeLuca et al., 2015), but also via indirect effects on P retention and release through changes in the soil microbial environment (Atkinson et al., 2010). It has previously been proposed that the degrees of changes in P availability are highly dependent on biochar feedstock type (Spokas et al., 2012) and biochar pyrolysis temperature (Zwetsloot et al., 2015). A previous study on the effect of pyrolysis temperature on P adsorption derived from macroalgae biochar revealed that the $\mathrm{P}$ adsorption capacity initially increased $\left(200\right.$ to $\left.400{ }^{\circ} \mathrm{C}\right)$ and then decreased $\left(400\right.$ to $800{ }^{\circ} \mathrm{C}$ ) with increasing pyrolysis temperature (Jung et al., 2016). Shi et al. (2016) showed that the increased $\mathrm{P}$ adsorption capacity slightly decreased at $750{ }^{\circ} \mathrm{C}$ in sewage sludge biochar. Collectively, the findings of these previous studies indicate that $\mathrm{P}$ adsorption and desorption of biochar are dependent on the feedstock and pyrolysis temperature.

In this study, treatments using three feedstock types of biochar (produced at six pyrolysis temperatures) were employed to determine the effects of biochar amendment on soil $\mathrm{P}$ sorption-desorption. This study aimed to assess the potential of biochar amendment to improve $\mathrm{P}$ availability and identify the influence of biochar feedstock type and pyrolysis temperature on the $\mathrm{P}$ availability in biochar amended black soil from Northeast China.

\section{MATERIALS AND METHODS}

\section{Soil sampling}

Soil samples were collected from Keshan Farm in the black soil region of northeast China $\left(48^{\circ} 12^{\prime}-48^{\circ} 23^{\prime}\right.$ N, $125^{\circ} 08^{\prime}$ $125^{\circ} 37^{\prime}$ E) (Figure 1) (Zhao et al., 2018) because the study area represents typical soil type and tillage practices in the region. Arable surface soils samples $(0-10 \mathrm{~cm}$ soil depth) were collected from five randomly assigned points in the study site. Soil samples were homogenized, air-dried at $25^{\circ} \mathrm{C}$, and passed through a $2 \mathrm{~mm}$ sieve, and then stored at $25^{\circ} \mathrm{C}$ until the incubation experiment. Soil in the study area was classified as a Mollisol according to the USDA soil taxonomy. Parent

Figure 1. Location of the study area.

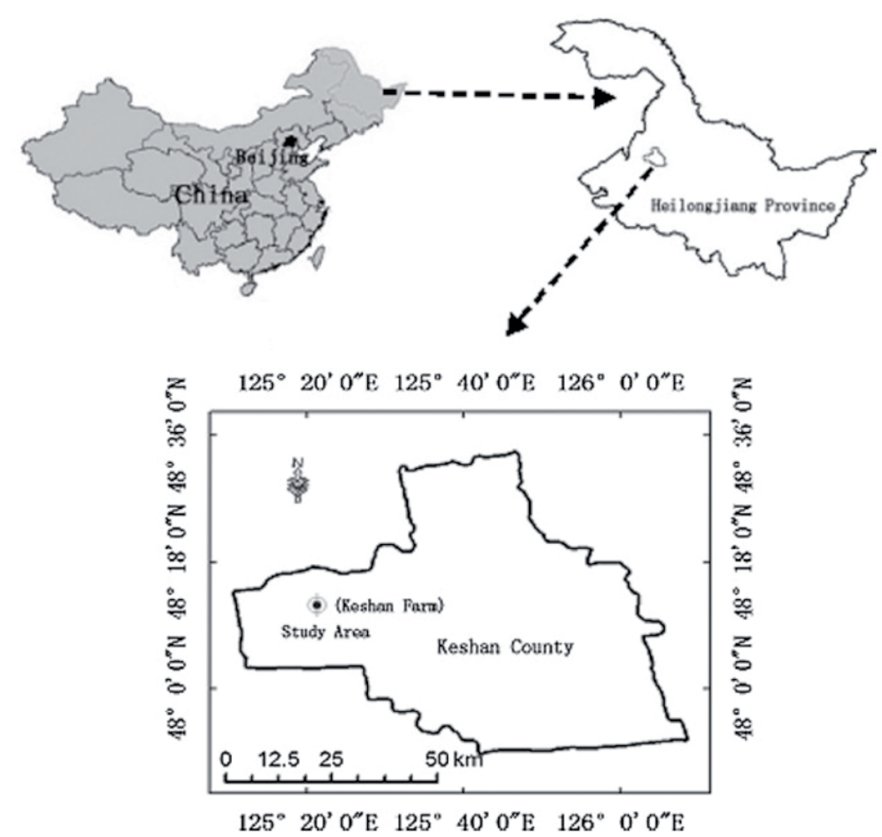


materials in this study area are characterized by "lithologic uniformity" represented by the loess and loess-like loams, and the soils had developed under meadow steppe vegetation (Kravchenko et al., 2011). Geomorphologic landscapes in the region are plain terraces and tablelands (Liu et al., 2012). The properties of the soil are bulk density: $1.09 \mathrm{~g} \mathrm{~cm}^{-3}, \mathrm{pH}$ : 5.77, soil organic C (SOC): $51.03 \mathrm{~g} \mathrm{~kg}^{-1}$, total P (TP): $0.86 \mathrm{~g} \mathrm{~kg}^{-1}$, total $\mathrm{N}$ (TN): $3.01 \mathrm{~g} \mathrm{~kg}^{-1}$, available P (AP): $43.05 \mathrm{mg} \mathrm{kg}^{-1}$, and available $\mathrm{N}(\mathrm{AN}): 120.25 \mathrm{mg} \mathrm{kg}^{-1}$. The proportion of sand, silt, and clay was $22 \%, 33 \%$, and $45 \%$, respectively. The annual mean temperature of the study area is $0.9{ }^{\circ} \mathrm{C}$, with a lowest monthly mean temperature of $-21.4{ }^{\circ} \mathrm{C}$ in January and a highest monthly mean temperature of $22.0^{\circ} \mathrm{C}$ in July. The mean annual precipitation is $501.7 \mathrm{~mm}, 68.3 \%$ of which is concentrated from June to August. The mean annual evaporation of this study area is $1329 \mathrm{~mm}$ (China Meteorological Data Service Center, 2018).

\section{Biochar production}

The applied biochar was composed of corn (Zea mays L.) cob (CC), soybean (Glycine max [L.] Merr.) pod (SP), and soybean straw (SS) that had been pyrolyzed at temperatures between 200 and $700{ }^{\circ} \mathrm{C}$ (i.e., at $200,300,400,500,600$, and $700{ }^{\circ} \mathrm{C}$ ) under anaerobic conditions (Lehmann et al., 2011). Biochar samples were labelled according to the feedstock type and temperature at which the biochar was pyrolyzed, e.g., $\mathrm{CC}$ biochar pyrolyzed at $200^{\circ} \mathrm{C}$ was labelled as $\mathrm{CC} 2$. The temperature was raised at a rate of approximately $13{ }^{\circ} \mathrm{C} \cdot \mathrm{min}^{-1}$ and maintained at the target temperature for $2 \mathrm{~h}$, after which the samples were allowed to cool to $25^{\circ} \mathrm{C}$. The biochar products were ground and passed through a $0.15 \mathrm{~mm}$ sieve before application.

\section{Experimental design}

Biochar types were each added uniformly to $400 \mathrm{~g}$ soil at a rate of $4 \%$ (Yao et al., 2017), and an incubation experiment using $500 \mathrm{~cm}^{3}$ plastic incubation containers was conducted for $60 \mathrm{~d}$ at $25{ }^{\circ} \mathrm{C}$ with a moisture content equal to $70 \%$ of the field capacity of the soil in the study area. Biochar amended soil samples were labelled according to the feedstock type and temperature at which the biochar was pyrolyzed, e.g., corncob biochar pyrolyzed at $200{ }^{\circ} \mathrm{C}$ was labelled as CC200. As a control (CT), soil samples without biochar amendment were incubated under the same conditions. All incubation experiments were conducted with four replicates.

\section{Determination of soil chemical properties}

Soil chemical properties were analyzed based on the methods described in Lu (1999). Soil pH was determined using the electrometric method using a suspension in deionized water (soil:water 1:2.5, w/v). Soil organic C (SOC) was measured using dry combustion using a total organic C analyzer (Elementar, Vario EL cube, Langenselbold, Germany). Soil total $\mathrm{N}$ (TN) was measured using the Kjeldahl distillation method. Soil total $\mathrm{P}(\mathrm{TP})$ was measured by digestion with a mixture of acids consisting of $\mathrm{H}_{2} \mathrm{SO}_{4}$ and $\mathrm{HClO}_{4}$, followed by the molybdenum blue method. The available $\mathrm{P}$ (AP) present in soil was extracted with $0.03 \mathrm{M} \mathrm{NH}_{4} \mathrm{~F}$ and $0.025 \mathrm{M} \mathrm{HCl}$ and measured using the molybdenum blue method. Soil available $\mathrm{N}$ (AN) was measured using the alkaline hydrolysis diffusion method. Each analysis was conducted with four replicates.

\section{Isothermal adsorption and desorption}

The $\mathrm{P}$ adsorption of each soil sample was examined by placing $1.5 \mathrm{~g}$ dried soil in $30 \mathrm{~mL} 0.01 \mathrm{~mol} \mathrm{~L}^{-1} \mathrm{KCl}(\mathrm{pH}=7)$ solution that contained $0,10,20,30,40,60,80,100$, and $120 \mathrm{mg} \mathrm{L}^{-1} \mathrm{P}$. Two drops of chloroform were added to the soil samples to prevent microbial activity. All the samples were shaken at $25{ }^{\circ} \mathrm{C}$ for $24 \mathrm{~h}$, centrifuged $\left(5000 \mathrm{r} \mathrm{min}^{-1}\right)$ for 10 $\mathrm{min}$, and filtered. The $\mathrm{P}$ concentration of the equilibrium solution was then determined by the molybdenum blue method. Desorption of soil $\mathrm{P}$ was measured after the supernatants obtained in the adsorption experiment were removed, and the residual soil samples were washed twice with $30 \mathrm{~mL}$ saturated $\mathrm{NaCl}$ to remove free P. After the samples were centrifuged and filtered, $30 \mathrm{~mL} 0.01 \mathrm{~mol} \mathrm{~L}^{-1} \mathrm{KCl}(\mathrm{pH}=7)$ and two drops of chloroform were mixed with each sample, followed by centrifugation. The supernatants were examined to determine the desorbed P content. Each analysis was conducted with four replicates.

Langmuir adsorption isotherms describe solute adsorption by solids in an aqueous solution at constant temperature and pressure. The $\mathrm{P}$ adsorption data for the soils used in the present study were fitted to the following Langmuir adsorption Equation [1]: 


$$
\frac{\mathrm{C}_{\mathrm{e}}}{\mathrm{Q}_{\mathrm{e}}}=\frac{\mathrm{C}_{\mathrm{e}}}{\mathrm{Q}_{\mathrm{m}}}+\frac{1}{\mathrm{~K}_{\mathrm{L}} \mathrm{Q}_{\mathrm{m}}}
$$

where, $C_{e}$ is the equilibrium $\mathrm{P}$ concentration in solution $\left(\mathrm{mg} \mathrm{L}^{-1}\right), Q_{e}$ is the mass of $\mathrm{P}$ adsorbed per unit mass of soil $\left(\mathrm{mg} \mathrm{kg}{ }^{-1}\right), K_{L}$ is the Langmuir constant related to bonding energy $\left(\mathrm{L} \mathrm{mg}^{-1}\right)$, and $Q_{m}$ is the sorption maximum $\left(\mathrm{mg} \mathrm{kg}^{-1}\right)$ calculated using the Langmuir equation. The maximum P buffer capacity (MBC) of the soil was calculated from the product of the Langmuir constants: $\mathrm{Q}_{\mathrm{m}}$ and $\mathrm{K}_{\mathrm{L}}$ (Lair et al., 2009).

Thermodynamic function that represents $\mathrm{P}$ adsorption was calculated using the Gibbs transformation Equation [2] (Kumar et al., 2013):

$$
\Delta \mathrm{G}^{\mathrm{o}}=-\mathrm{R} \ln \mathrm{K}_{\mathrm{m}}
$$

where, $\Delta G^{\circ}$ is the free energy of adsorption $\left(\mathrm{kJ} \mathrm{mol}^{-1}\right), R$ is the gas constant $\left(8.314 \mathrm{~J} \mathrm{~mol}^{-1} \mathrm{~K}^{-1}\right), T$ is the thermodynamic temperature $\left({ }^{\circ} \mathrm{K}\right), K_{m}$ is the thermodynamic equilibrium constant $\left(\mathrm{K}_{\mathrm{m}}=\mathrm{K}_{\mathrm{L}} \times 31000\right)$, which is the constant related to the binding energy in the Langmuir isotherm (Equation [1]).

The $\mathrm{P}$ desorption data for the soils used in the present study were fitted to the following Langmuir desorption Equation [3]:

$$
\frac{C_{e}}{D_{e}}=\frac{C_{e}}{D_{m}}+\frac{1}{K_{d} D_{m}}
$$

where, $C_{e}$ is the equilibrium $\mathrm{P}$ concentration in solution $\left(\mathrm{mg} \mathrm{L}^{-1}\right), D_{e}$ is the mass of $\mathrm{P}$ desorbed per unit mass of soil $\left(\mathrm{mg} \mathrm{kg}^{-1}\right)$, and $D_{m}$ is the desorption maximum $\left(\mathrm{mg} \mathrm{kg}^{-1}\right)$ calculated using the Langmuir Equation [3].

The sorption-desorption hysteresis index (HI) was quantified for each soil sample and calculated using the following Equation [4], defined by Deng et al. (2010):

$$
\mathrm{HI}=\left[\frac{\mathrm{D}_{\mathrm{e}}-\mathrm{Q}_{\mathrm{e}}}{\mathrm{Q}_{\mathrm{e}}}\right]_{\text {average }}
$$

where, $D_{e}\left(\mathrm{mg} \mathrm{kg}^{-1}\right)$ and $Q_{e}\left(\mathrm{mg} \mathrm{kg}^{-1}\right)$ are solid-phase solute concentrations for desorption and sorption processes, respectively (Zhang et al., 2017). An average value of desorption ratio $\left(\mathrm{D}_{\text {avg }}\right)$ was defined as the average ratio of the desorbed phosphate to the total phosphate adsorbed by the adsorbents.

\section{Statistical analyses}

A one-way ANOVA with least significant difference (LSD) was used to assess significant differences in the chemical properties of soil, biochar, and biochar-amended soil, and significant differences in $\mathrm{P}$ adsorption and desorption parameters among biochar amendment treatments with different feedstock types and pyrolysis temperatures. Linear regression analysis was applied to the Langmuir isotherms of $\mathrm{P}$ adsorption and desorption on soil and biochar-amended soil with different feedstock types and pyrolysis temperatures. All statistical analyses were conducted using SPSS 22.0 (IBM, Armonk, New York, USA) with a significance threshold of $\mathrm{p}<0.05$.

\section{RESULTS}

\section{Phosphorus contents in soil and biochar properties}

The total P (TP) in the three kinds of biochar increased with pyrolysis temperature (Table 1). In contrast, the contents of available $\mathrm{P}(\mathrm{AP})$ decreased with increasing pyrolysis temperature because of increases in volatilization during pyrolysis (Zhou et al., 2017). However, a common trend was seen in that the TP and AP values of SP and SS were higher than those of CC. After biochar application, TP and AP contents generally increased. The TP of biochar amended soil using all three feedstock types showed an increasing trend with increasing pyrolysis temperature. The values of TP in SS were higher than in CC and SP for each pyrolysis temperature due to the effects of biochar (Sohi et al., 2010; Sun and Lu, 2014). The variation in AP was similar to that in TP, probably owing to the interaction between biochar and soil (DeLuca et al., 2015). 
Table 1. Total $P$ (TP) and available $P(A P)$ contents of three types of biochar pyrolyzed at temperature between 200 and $700{ }^{\circ} \mathrm{C}$ under anaerobic conditions and biochar amended black soil.

\begin{tabular}{|c|c|c|c|c|c|}
\hline Biochar & $\mathrm{TP}$ & AP & $\begin{array}{c}\text { Soil } \\
\text { samples }\end{array}$ & TP & AP \\
\hline & $\mathrm{g} \mathrm{kg}^{-1}$ & $\mathrm{mg} \mathrm{kg}^{-1}$ & & $\mathrm{~g} \mathrm{~kg}^{-1}$ & $\mathrm{mg} \mathrm{kg}^{-1}$ \\
\hline & & & $\mathrm{CT}$ & $0.86 \pm 0.02 \mathrm{bc}$ & $43.05 \pm 1.29 \mathrm{~cd}$ \\
\hline $\mathrm{CC} 2$ & $1.05 \pm 0.04 \mathrm{~dB}$ & $81.02 \pm 4.01 \mathrm{aB}$ & CC200 & $0.83 \pm 0.05 \mathrm{cB}$ & $41.42 \pm 2.84 \mathrm{cB}$ \\
\hline $\mathrm{CC} 3$ & $1.08 \pm 0.02 \mathrm{dC}$ & $77.13 \pm 2.52 \mathrm{abB}$ & CC300 & $0.84 \pm 0.05 \mathrm{cB}$ & $44.95 \pm 2.36 \mathrm{bcdC}$ \\
\hline $\mathrm{CC} 4$ & $1.19 \pm 0.06 \mathrm{cB}$ & $70.07 \pm 7.86 \mathrm{bC}$ & $\mathrm{CC} 400$ & $0.90 \pm 0.03 \mathrm{abA}$ & $47.33 \pm 2.89 \mathrm{bcC}$ \\
\hline $\mathrm{CC} 5$ & $1.37 \pm 0.06 \mathrm{bB}$ & $56.80 \pm 1.78 \mathrm{cC}$ & CC500 & $0.86 \pm 0.02 \mathrm{bcB}$ & $46.96 \pm 0.61 \mathrm{bcB}$ \\
\hline CC6 & $1.42 \pm 0.10 \mathrm{bB}$ & $47.45 \pm 6.42 \mathrm{~dB}$ & CC600 & $0.84 \pm 0.02 \mathrm{cB}$ & $57.56 \pm 2.93 \mathrm{aB}$ \\
\hline \multirow[t]{2}{*}{$\mathrm{CC} 7$} & $1.52 \pm 0.08 \mathrm{aB}$ & $44.95 \pm 3.74 \mathrm{~dB}$ & $\mathrm{CC} 700$ & $0.93 \pm 0.06 \mathrm{aB}$ & $48.89 \pm 6.61 \mathrm{bB}$ \\
\hline & & & $\mathrm{CT}$ & $0.86 \pm 0.02 \mathrm{~d}$ & $43.05 \pm 1.29 c$ \\
\hline SP2 & $1.11 \pm 0.08 \mathrm{aB}$ & $95.90 \pm 3.96 \mathrm{aB}$ & SP200 & $0.95 \pm 0.05 \mathrm{bcA}$ & $42.70 \pm 1.91 \mathrm{dA}$ \\
\hline SP3 & $1.20 \pm 0.04 \mathrm{abB}$ & $89.00 \pm 2.87 \mathrm{abB}$ & SP300 & $0.93 \pm 0.05 \mathrm{cdA}$ & $57.44 \pm 2.58 \mathrm{bB}$ \\
\hline SP4 & $1.34 \pm 0.14 \mathrm{bcAB}$ & $83.59 \pm 4.13 \mathrm{bcB}$ & SP400 & $0.94 \pm 0.04 \mathrm{cdA}$ & $60.67 \pm 3.59 \mathrm{bB}$ \\
\hline SP5 & $1.47 \pm 0.13 \mathrm{cB}$ & $78.96 \pm 5.95 \mathrm{cB}$ & SP500 & $1.03 \pm 0.06 \mathrm{abA}$ & $54.48 \pm 10.54 \mathrm{bcB}$ \\
\hline SP6 & $1.72 \pm 0.10 \mathrm{dA}$ & $82.75 \pm 6.48 \mathrm{bcA}$ & SP600 & $1.10 \pm 0.11 \mathrm{aA}$ & $79.08 \pm 13.96 \mathrm{aA}$ \\
\hline \multirow[t]{2}{*}{ SP7 } & $1.66 \pm 0.16 \mathrm{dAB}$ & $64.56 \pm 4.00 \mathrm{dA}$ & SP700 & $1.02 \pm 0.02 \mathrm{abcA}$ & $56.82 \pm 10.69 \mathrm{bAB}$ \\
\hline & & & $\mathrm{CT}$ & $0.86 \pm 0.02 \mathrm{~d}$ & $43.05 \pm 1.29 \mathrm{~d}$ \\
\hline SS2 & $1.22 \pm 0.07 \mathrm{aA}$ & $117.05 \pm 15.82 \mathrm{aA}$ & SS200 & $0.99 \pm 0.07 \mathrm{bcA}$ & $62.11 \pm 1.91 \mathrm{cA}$ \\
\hline SS3 & $1.34 \pm 0.05 \mathrm{abA}$ & $123.25 \pm 16.41 \mathrm{abA}$ & SS300 & $1.00 \pm 0.02 \mathrm{bcdA}$ & $67.09 \pm 1.50 \mathrm{abcA}$ \\
\hline SS4 & $1.46 \pm 0.11 \mathrm{bA}$ & $100.76 \pm 7.24 \mathrm{bcA}$ & SS400 & $0.96 \pm 0.05 \mathrm{cA}$ & $76.09 \pm 9.22 \mathrm{aA}$ \\
\hline SS5 & $1.73 \pm 0.10 \mathrm{cA}$ & $91.10 \pm 7.30 \mathrm{cdA}$ & SS500 & $1.03 \pm 0.05 \mathrm{abA}$ & $72.79 \pm 5.23 \mathrm{abA}$ \\
\hline SS6 & $1.80 \pm 0.14 \mathrm{cA}$ & $82.28 \pm 9.77 \mathrm{dA}$ & SS600 & $1.07 \pm 0.05 \mathrm{aA}$ & $71.61 \pm 11.48 \mathrm{abAB}$ \\
\hline SS7 & $1.88 \pm 0.22 \mathrm{cA}$ & $74.03 \pm 8.81 \mathrm{dA}$ & SS700 & $0.95 \pm 0.02 \mathrm{cB}$ & $63.95 \pm 4.99 \mathrm{bcA}$ \\
\hline
\end{tabular}

Different lower-case letters in the same feedstock biochar indicate a significant difference among soil and biochar-amended soil with different pyrolysis temperatures at $\mathrm{p}<0.05$.

Different uppercase letters in the same pyrolysis temperatures indicate significant differences between three types biochar-amended soil at $\mathrm{p}<0.05$.

CC: Corncob; SP: soybean pod; SS: soybean straw; CT: control (i.e., no biochar amendment).

\section{Phosphorus adsorption}

Adsorption procedures have been suggested for use in predicting the partition of $\mathrm{P}$ between solution and solid phases in the environment (Wang et al., 2007). The relationship between P equilibrium concentration and the amount of adsorbed $P$ are expressed as linear correlations in Figure 2. The P adsorption data of each sample could be described by the Langmuir $\left(\mathrm{R}^{2}>0.54\right)$ isotherm. At an equilibrium P concentration of $7 \mathrm{mg} \mathrm{L}^{-1}, \mathrm{CC} 200, \mathrm{CC} 300$, and CC400 had the lowest $\mathrm{Q}_{\mathrm{e}}$ values (i.e., 322.99, 328.42, and $321.87 \mathrm{mg} \mathrm{kg}^{-1}$, respectively), followed by higher $\mathrm{Q}_{\mathrm{e}}$ values for CC500, CC600, and CC700 (i.e., $372.53,359.94$, and $356.20 \mathrm{mg} \mathrm{kg}^{-1}$, respectively), which were comparable to CT (360.20 mg kg-1) (Figure 2a). However, the $\mathrm{Q}_{\mathrm{e}}$ values of CC500, CC600, and CC700 (i.e., 501.25, 527.07, and $456.54 \mathrm{mg} \mathrm{kg}^{-1}$, respectively) were lower than those of CC200, CC300, and CC400 (i.e., 1033.78, 1055.25, and $1024.23 \mathrm{mg} \mathrm{kg}^{-1}$, respectively) and CT (1289.90 $\mathrm{mg} \mathrm{kg}^{-1}$ ) at > $35 \mathrm{mg} \mathrm{L}^{-1}$ equilibrium concentration. Compared with CC, differences were shown in SP and SS. The SP200 and SP300 always had the lowest $\mathrm{Q}_{e}$, followed by treatments using biochar from pyrolysis temperatures 400 to $700{ }^{\circ} \mathrm{C}$, which were comparable to that of CT (Figure 2b). In Figure 2c, the $\mathrm{Q}_{\mathrm{e}}$ values of SS200 and SS300 were lower than those from the other SS amended soils and $\mathrm{CT}$ at $>40 \mathrm{mg} \mathrm{L}^{-1}$ equilibrium concentration.

Soil $\mathrm{P}$ adsorption parameters from biochar from different feedstock types and pyrolysis temperatures, calculated by Langmuir isotherms, are shown in Table 2. The response of $\mathrm{P}$ adsorption in soil was highly dependent on biochar feedstock types and pyrolysis temperature. The sorption maximum $\left(\mathrm{Q}_{\mathrm{m}}\right)$ of CC decreased from 1428.57 to $556.70 \mathrm{mg} \mathrm{kg}^{-1}$ when pyrolysis temperature increased. The values of $\mathrm{Q}_{\mathrm{m}}$ in SP and SS biochar amended soil were at a maximum at $400{ }^{\circ} \mathrm{C}$ and then slightly decreased with further increase in pyrolysis temperature. The effect of biochar feedstock types and pyrolysis temperatures on $\mathrm{P}$ adsorption intensity $\left(\mathrm{K}_{\mathrm{L}}\right)$ and free energy $\left(\Delta \mathrm{G}^{\circ}\right)$ were also obvious in biochar-amended soil. Adsorption free energy $\left(\Delta \mathrm{G}^{\circ}\right)$ could reflect the extent of spontaneous adsorptive reactions, i.e., the greater the degree of spontaneity, the stronger the $\mathrm{P}$ adsorption. In this study, $\Delta \mathrm{G}^{\circ}$ values were less than 0 , indicating that adsorption was a spontaneous process. After biochar amendment, $\mathrm{K}_{\mathrm{L}}$ and absolute value $\Delta \mathrm{G}^{\circ}$ of $\mathrm{CC}$ and SP raised while SS slightly 
Figure 2. Langmuir isotherm of $\mathbf{P}$ adsorption on amended black soil using biochar from different feedstock types and pyrolysis temperatures (ranging from 200 to $700{ }^{\circ} \mathrm{C}$ ).
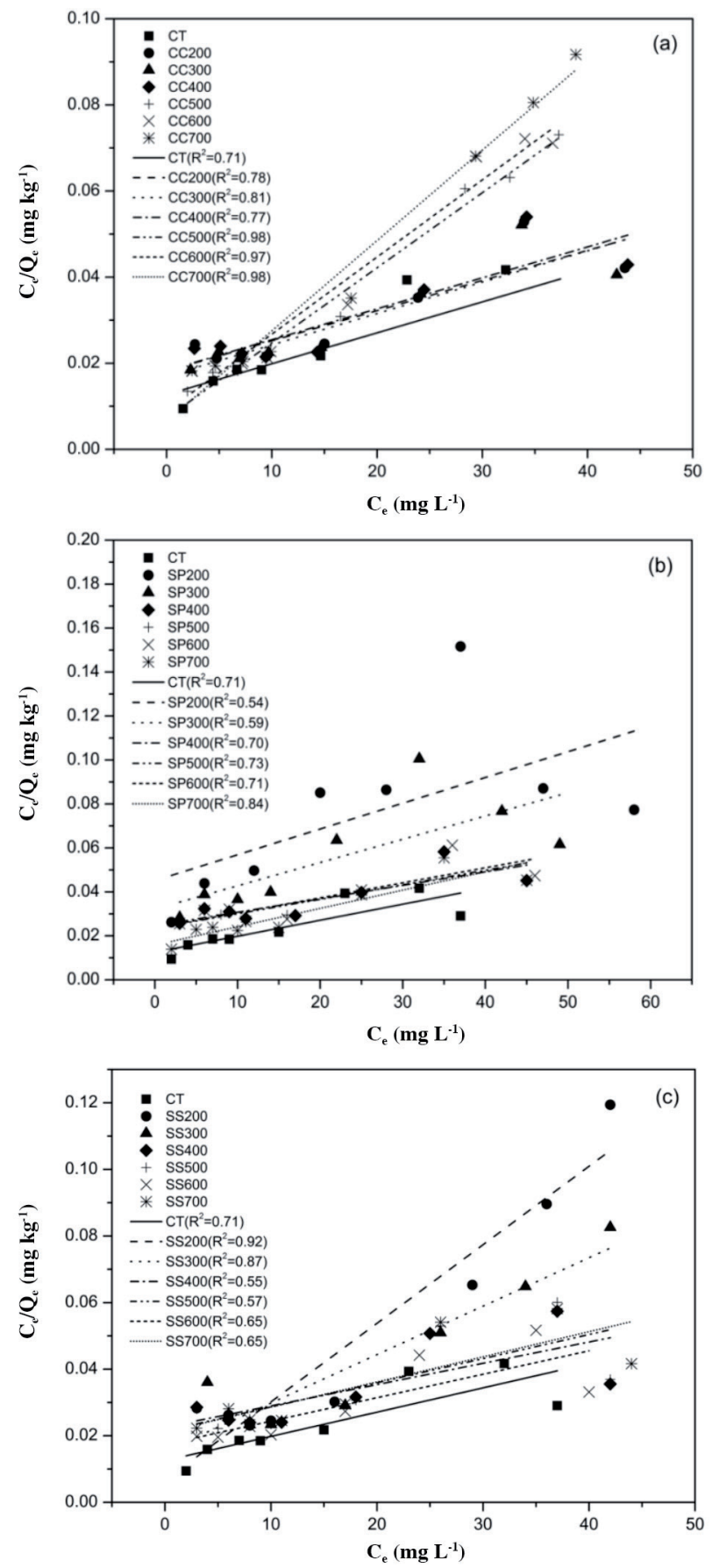

(a), (b), and (c) represent corncob (CC) biochar, soybean pod (SP) biochar, and soybean straw (SS) biochar, respectively. CT: Control (i.e., no biochar amendment); $\mathrm{C}_{\mathrm{e}}$ : equilibrium P concentration in solution; $\mathrm{Q}_{\mathrm{e}}$ : solid-phase solute concentrations for sorption processes.

Lines represent trend lines relative to the data points. The $\mathrm{R}^{2}$ is the coefficient of determination between the data points and the trend line. 
Table 2. Parameters of $P$ adsorption on black soil and amended black soil using biochar from different feedstocks and pyrolysis temperatures (between 200 and $700{ }^{\circ} \mathrm{C}$ ).

\begin{tabular}{lclcc}
\hline $\begin{array}{l}\text { Soil } \\
\text { samples }\end{array}$ & \multicolumn{1}{c}{$\mathrm{Q}_{\mathrm{m}}$} & \multicolumn{1}{c}{$\mathrm{K}_{\mathrm{L}}$} & $\mathrm{MBC}$ & \multicolumn{1}{c}{$\mathrm{G}^{\circ}$} \\
\hline & $\mathrm{mg} \mathrm{kg}$ & \multicolumn{1}{c}{$\mathrm{L} \mathrm{mg}^{-1}$} & $\mathrm{~L} \mathrm{~kg}^{-1}$ & $\mathrm{~kJ} \mathrm{~mol}^{-1}$ \\
CT & $1383.93 \pm 89.29 \mathrm{a}$ & $0.0575 \pm 0.0058 \mathrm{c}$ & $79.28 \pm 4.93 \mathrm{~d}$ & $-18.54 \pm 0.24 \mathrm{~b}$ \\
CC200 & $1428.57 \pm 0.00 \mathrm{aA}$ & $0.0386 \pm 0.0023 \mathrm{cB}$ & $55.10 \pm 3.31 \mathrm{eB}$ & $-17.55 \pm 0.15 \mathrm{aA}$ \\
CC300 & $1383.93 \pm 89.29 \mathrm{aA}$ & $0.0431 \pm 0.0062 \mathrm{cA}$ & $59.24 \pm 4.44 \mathrm{eA}$ & $-17.81 \pm 0.34 \mathrm{aA}$ \\
CC400 & $1383.93 \pm 89.29 \mathrm{aB}$ & $0.0398 \pm 0.0041 \mathrm{cA}$ & $54.81 \pm 2.54 \mathrm{eA}$ & $-17.63 \pm 0.25 \mathrm{aC}$ \\
CC500 & $571.90 \pm 18.87 \mathrm{bC}$ & $0.2412 \pm 0.0189 \mathrm{aA}$ & $137.73 \pm 7.07 \mathrm{aA}$ & $-22.09 \pm 0.19 \mathrm{~dB}$ \\
CC600 & $558.30 \pm 46.56 \mathrm{bB}$ & $0.2024 \pm 0.0229 \mathrm{bA}$ & $112.24 \pm 5.52 \mathrm{cA}$ & $-21.65 \pm 0.28 \mathrm{cC}$ \\
CC700 & $556.70 \pm 30.98 \mathrm{bB}$ & $0.2150 \pm 0.0222 \mathrm{abA}$ & $119.23 \pm 5.68 \mathrm{bA}$ & $-21.87 \pm 0.24 \mathrm{cdC}$ \\
\hline CT & $1383.93 \pm 89.29 \mathrm{abc}$ & $0.0575 \pm 0.0058 \mathrm{a}$ & $79.28 \pm 4.93 \mathrm{a}$ & $-18.54 \pm 0.24 \mathrm{~b}$ \\
SP200 & $855.65 \pm 276.40 \mathrm{~dB}$ & $0.0294 \pm 0.0085 \mathrm{bcB}$ & $23.67 \pm 3.08 \mathrm{dC}$ & $-16.80 \pm 0.71 \mathrm{aA}$ \\
SP300 & $1119.05 \pm 504.70 \mathrm{cdA}$ & $0.0337 \pm 0.0074 \mathrm{bA}$ & $35.49 \pm 11.71 \mathrm{cA}$ & $-17.17 \pm 0.59 \mathrm{aA}$ \\
SP400 & $1666.67 \pm 0.00 \mathrm{aA}$ & $0.0244 \pm 0.0009 \mathrm{cB}$ & $40.69 \pm 1.49 \mathrm{cC}$ & $-16.42 \pm 0.09 \mathrm{aA}$ \\
SP500 & $1488.10 \pm 119.05 \mathrm{abA}$ & $0.0291 \pm 0.0039 \mathrm{bcB}$ & $42.92 \pm 2.76 \mathrm{cB}$ & $-16.84 \pm 0.35 \mathrm{aA}$ \\
SP600 & $1443.45 \pm 170.97 \mathrm{abcA}$ & $0.0298 \pm 0.0054 \mathrm{bcB}$ & $42.38 \pm 2.91 \mathrm{cC}$ & $-16.89 \pm 0.42 \mathrm{aA}$ \\
SP700 & $1203.70 \pm 65.47 \mathrm{bcA}$ & $0.0529 \pm 0.0029 \mathrm{aB}$ & $63.43 \pm 0.50 \mathrm{bB}$ & $-18.33 \pm 0.14 \mathrm{bB}$ \\
\hline CT & $1383.93 \pm 89.29 \mathrm{a}$ & $0.0575 \pm 0.0058 \mathrm{~b}$ & $79.28 \pm 4.93 \mathrm{ab}$ & $-18.54 \pm 0.24 \mathrm{a}$ \\
SS200 & $428.84 \pm 43.55 \mathrm{bC}$ & $0.3958 \pm 0.2062 \mathrm{aA}$ & $129.32 \pm 24.90 \mathrm{aA}$ & $-23.09 \pm 1.24 \mathrm{bB}$ \\
SS300 & $1221.15 \pm 900.57 \mathrm{aA}$ & $0.2035 \pm 0.2921 \mathrm{abA}$ & $99.96 \pm 96.63 \mathrm{abA}$ & $-19.38 \pm 4.02 \mathrm{aA}$ \\
SS400 & $1547.62 \pm 137.46 \mathrm{aA}$ & $0.0293 \pm 0.0043 \mathrm{bB}$ & $44.89 \pm 2.89 \mathrm{bB}$ & $-16.85 \pm 0.37 \mathrm{aB}$ \\
SS500 & $1339.29 \pm 103.10 \mathrm{aB}$ & $0.0357 \pm 0.0063 \mathrm{bB}$ & $47.36 \pm 4.76 \mathrm{bB}$ & $-17.34 \pm 0.44 \mathrm{aA}$ \\
SS600 & $1443.45 \pm 170.97 \mathrm{aA}$ & $0.0408 \pm 0.0071 \mathrm{bB}$ & $58.04 \pm 3.51 \mathrm{bB}$ & $-17.67 \pm 0.43 \mathrm{aB}$ \\
SS700 & $1395.83 \pm 328.96 \mathrm{aA}$ & $0.0374 \pm 0.0152 \mathrm{bB}$ & $48.54 \pm 7.82 \mathrm{bC}$ & $-17.33 \pm 1.00 \mathrm{aA}$ \\
\hline Q & & & &
\end{tabular}

$\mathrm{Q}_{\mathrm{m}}$ : Langmuir sorption maximum; $\mathrm{K}_{\mathrm{L}}$ : bonding energy constant; $\mathrm{MBC}$ : maximum buffer capacity; $\Delta \mathrm{G}^{\circ}$ : free energy of adsorption. CT represents the control (i.e., no biochar amendment); CC: corncob; SP: soybean pod; SS: soybean straw.

Different lower-case letters in the same biochar feedstock indicate significant differences among soil and biocharamended soil with different pyrolysis temperatures at $\mathrm{p}<0.05$. Different uppercase letters in the same pyrolysis temperatures indicate significant differences among three types biochar-amended soil at $\mathrm{p}<0.05$.

decreased with increasing pyrolysis temperature. Different pyrolysis and feedstock biochar led to variations in soil MBC. The variations in $\mathrm{MBC}$ under increasing pyrolysis temperatures were analogous to the absolute value of $\Delta \mathrm{G}^{\circ}$, indicating that the variety of adsorption capacity was due to the changing standard free energy that was involved in the transfer of $\mathrm{P}$ from soil solutions to solids.

\section{Phosphorus desorption}

Desorption of $\mathrm{P}$ in soil is a reversible process which is directly related to adsorbed $\mathrm{P}$ re-use and the bioavailability of soil (Zhang et al., 2011). Phosphorus adsorbed by the soil solid phase was partially desorbed, and the amount of $\mathrm{P}$ increases as the initial $\mathrm{P}$ concentration increases (Table 3). In $40 \mathrm{mg} \mathrm{L}^{-1}$, the concentration of desorbed $\mathrm{P}$ at higher pyrolysis temperatures $\left(500\right.$ to $700{ }^{\circ} \mathrm{C}$ ) were significantly lower than the $\mathrm{P}$ loads at lower pyrolysis temperatures (200 to $\left.400{ }^{\circ} \mathrm{C}\right)$ in $\mathrm{CC}$ while higher concentration of desorbed $\mathrm{P}$ was observed at $\left(500\right.$ to $\left.700{ }^{\circ} \mathrm{C}\right)$ in SP and SS. This difference may be due to the significant changes in binding energy (Table 2), and a decrease in binding energy suggests higher $\mathrm{P}$ desorption. The decrease in binding energy is attributed to the increase in $\mathrm{pH}$ with biochar application (Xu et al., 2014). The P desorption in CC was apparently more sensitive to biochar amendment than in SP and SS at $200{ }^{\circ} \mathrm{C}$. However, $\mathrm{P}$ desorption values in SP and SS gradually increased with increasing pyrolysis temperature and were subsequently higher than $\mathrm{CC}$ from higher pyrolysis temperatures (i.e., $>500^{\circ} \mathrm{C}$ ).

An average value of desorption ratio $\left(\mathrm{D}_{\text {avg }}\right)$ can be used to indicate the degree of $\mathrm{P}$ desorption from the adsorptive materials (Cui et al., 2011). Biochar amendment enhanced the $\mathrm{P}$ desorbability of black soil, and the values of $\mathrm{D}_{\text {avg }}$ were generally higher than $\mathrm{CT}$ except in $\mathrm{CC}$ at $500{ }^{\circ} \mathrm{C}$ (Table 4). Desorption maximum $\left(\mathrm{D}_{\mathrm{m}}\right)$, i.e., the maximum amount of $\mathrm{P}$ desorption when $\mathrm{P}$ adsorption is saturated in soil, can indirectly reflect the P desorption capacity of soil (Yang et al., 2014). An increasing pyrolysis temperature caused a decline in the $\mathrm{D}_{\mathrm{m}}$ of $\mathrm{CC}$, but $\mathrm{D}_{\mathrm{m}}$ of the SP and SS enhanced with raising pyrolysis temperature, which indicates that their potential desorption capacity were enhanced. Comparisons of the three 
Table 3. Concentrations of $P$ desorption on black soil and amended black soil using biochar from different feedstocks and pyrolysis temperatures (between 200 and $700^{\circ} \mathrm{C}$ ).

\begin{tabular}{|c|c|c|c|c|c|c|c|c|}
\hline \multirow{2}{*}{$\begin{array}{l}\text { Soil } \\
\text { samples }\end{array}$} & \multicolumn{8}{|c|}{ Added $\mathrm{P}$ concentration $\left(\mathrm{mg} \mathrm{L}^{-1}\right)$} \\
\hline & 10 & 20 & 30 & 40 & 60 & 80 & 100 & 120 \\
\hline CT & $52.58 \pm 2.47 \mathrm{a}$ & $101.30 \pm 3.90 \mathrm{ab}$ & $154.61 \pm 4.80 \mathrm{a}$ & $187.44 \pm 12.94 a b$ & $245.43 \pm 18.20 b$ & $292.08 \pm 8.35 \mathrm{a}$ & $313.67 \pm 7.25 \mathrm{a}$ & $398.66 \pm 27.05 \mathrm{a}$ \\
\hline CC200 & $42.75 \pm 0.85 \mathrm{bcA}$ & $95.61 \pm 2.52 \mathrm{abA}$ & $151.21 \pm 5.21 \mathrm{abB}$ & $201.33 \pm 5.33 \mathrm{aB}$ & $290.12 \pm 9.27 \mathrm{aA}$ & $287.90 \pm 4.59 \mathrm{aA}$ & $321.00 \pm 12.88 \mathrm{aA}$ & $337.51 \pm 8.79 \mathrm{bA}$ \\
\hline CC300 & $41.56 \pm 2.00 \mathrm{bcB}$ & $93.00 \pm 1.06 \mathrm{bA}$ & $147.81 \pm 6.94 \mathrm{abA}$ & $195.03 \pm 3.39 \mathrm{abAB}$ & $295.24 \pm 10.89 \mathrm{aA}$ & $287.52 \pm 3.71 \mathrm{aAB}$ & $308.88 \pm 3.18 \mathrm{aAB}$ & $330.58 \pm 6.28 \mathrm{bA}$ \\
\hline CC400 & $43.27 \pm 2.05 b C$ & $105.43 \pm 10.96 \mathrm{aB}$ & $144.88 \pm 7.87 \mathrm{bB}$ & $195.12 \pm 8.46 \mathrm{abA}$ & $303.07 \pm 17.22 \mathrm{aAB}$ & $299.50 \pm 17.83 \mathrm{aA}$ & $320.54 \pm 14.61 \mathrm{aA}$ & $334.88 \pm 14.39 \mathrm{bB}$ \\
\hline CC500 & $42.46 \pm 0.74 \mathrm{bcB}$ & $73.38 \pm 1.14 \mathrm{cC}$ & $108.93 \pm 2.95 \mathrm{dC}$ & $156.10 \pm 9.35 \mathrm{cC}$ & $189.10 \pm 4.57 \mathrm{dC}$ & $210.60 \pm 17.85 \mathrm{cB}$ & $228.11 \pm 3.64 \mathrm{cC}$ & $232.23 \pm 2.34 \mathrm{dC}$ \\
\hline CC600 & $39.44 \pm 1.43 \mathrm{bcC}$ & $95.79 \pm 1.60 \mathrm{abB}$ & $143.88 \pm 4.58 \mathrm{bB}$ & $183.75 \pm 5.14 \mathrm{bB}$ & $223.27 \pm 1.07 \mathrm{cC}$ & $246.64 \pm 5.13 b C$ & $255.42 \pm 5.02 \mathrm{bC}$ & $259.7 \pm 2.6 \mathrm{cB}$ \\
\hline CC700 & $38.93 \pm 6.17 \mathrm{cB}$ & $80.99 \pm 14.49 \mathrm{cB}$ & $133.91 \pm 9.87 \mathrm{cB}$ & $166.15 \pm 19.38 \mathrm{cC}$ & $202.42 \pm 23.79 \mathrm{cdB}$ & $231.33 \pm 22.01 \mathrm{bB}$ & $233.15 \pm 23.68 \mathrm{cB}$ & $243.55 \pm 16.39 \mathrm{cdC}$ \\
\hline CT & $52.58 \pm 2.47 \mathrm{a}$ & $101.30 \pm 3.90 \mathrm{a}$ & $154.61 \pm 4.80 \mathrm{bc}$ & $187.44 \pm 12.94 b$ & & $292.08 \pm 8.35 b$ & $313.67 \pm 7.25 \mathrm{c}$ & $398.66 \pm 27.05 \mathrm{a}$ \\
\hline SP200 & $40.18 \pm 3.56 \mathrm{cA}$ & $73.72 \pm 9.48 \mathrm{cB}$ & $175.29 \pm 4.11 \mathrm{abA}$ & $249.33 \pm 27.56 \mathrm{aA}$ & $248.84 \pm 15.98 \mathrm{bB}$ & $247.42 \pm 21.41 \mathrm{cB}$ & $301.95 \pm 23.59 \mathrm{cA}$ & $353.85 \pm 16.96 \mathrm{bA}$ \\
\hline SP300 & $48.07 \pm 3.71 \mathrm{abB}$ & $103.38 \pm 1.48 \mathrm{aA}$ & $185.83 \pm 37.35 \mathrm{aA}$ & $260.88 \pm 53.02 \mathrm{aA}$ & $309.56 \pm 8.73 \mathrm{aA}$ & $323.98 \pm 7.68 \mathrm{aA}$ & $337.42 \pm 6.24 \mathrm{bA}$ & $349.27 \pm 18.85 \mathrm{bA}$ \\
\hline SP400 & $50.34 \pm 2.77 \mathrm{abB}$ & $104.25 \pm 1.99 \mathrm{aB}$ & $154.93 \pm 3.13 \mathrm{bcA}$ & $212.54 \pm 9.01 \mathrm{bA}$ & $311.16 \pm 25.54 \mathrm{aA}$ & $325.20 \pm 12.71 \mathrm{aA}$ & $335.91 \pm 12.48 \mathrm{bA}$ & $356.44 \pm 6.02 \mathrm{bB}$ \\
\hline SP500 & $47.63 \pm 3.07 \mathrm{abB}$ & $99.91 \pm 3.49 \mathrm{abB}$ & $152.28 \pm 2.46 \mathrm{cB}$ & $205.72 \pm 4.44 \mathrm{bB}$ & $309.34 \pm 20.53 \mathrm{aA}$ & $325.24 \pm 8.27 \mathrm{aA}$ & $347.95 \pm 6.15 \mathrm{abA}$ & $359.02 \pm 6.03 \mathrm{bB}$ \\
\hline SP600 & $46.00 \pm 4.92 \mathrm{bB}$ & $100.46 \pm 4.40 \mathrm{aB}$ & $145.53 \pm 10.48 \mathrm{cB}$ & $197.76 \pm 1.65 \mathrm{bA}$ & $325.61 \pm 31.95 \mathrm{aA}$ & $332.96 \pm 12.09 \mathrm{aA}$ & $358.09 \pm 16.73 \mathrm{aA}$ & $365.22 \pm 5.00 \mathrm{bA}$ \\
\hline SP700 & $40.03 \pm 2.21 \mathrm{cB}$ & $92.98 \pm 3.71 \mathrm{bB}$ & $140.44 \pm 5.64 \mathrm{cB}$ & $193.72 \pm 8.31 \mathrm{bB}$ & $306.79 \pm 3.46 \mathrm{aA}$ & $322.29 \pm 10.94 \mathrm{aA}$ & $337.24 \pm 9.59 \mathrm{bA}$ & $358.69 \pm 8.00 \mathrm{bB}$ \\
\hline $\mathrm{CT}$ & $52.58 \pm 2.47 b$ & $101.30 \pm 3.90 b c$ & $154.61 \pm 4.80 \mathrm{bc}$ & $187.44 \pm 12.94 a b$ & $245.43 \pm 18.20 b$ & $292.08 \pm 8.35 \mathrm{ab}$ & $313.67 \pm 7.25 \mathrm{a}$ & $398.66 \pm 27.05 \mathrm{a}$ \\
\hline SS200 & $39.84 \pm 1.34 \mathrm{cA}$ & $70.63 \pm 5.67 \mathrm{dA}$ & $121.36 \pm 5.85 \mathrm{dC}$ & $156.31 \pm 4.85 b C$ & $189.76 \pm 6.36 \mathrm{cC}$ & $203.61 \pm 5.84 \mathrm{cC}$ & $212.94 \pm 3.66 \mathrm{cB}$ & $215.78 \pm 8.21 \mathrm{bB}$ \\
\hline SS300 & $55.80 \pm 5.99 \mathrm{abA}$ & $94.81 \pm 22.33 \mathrm{cA}$ & $145.73 \pm 34.67 \mathrm{cA}$ & $181.83 \pm 51.08 \mathrm{abB}$ & $240.31 \pm 51.65 \mathrm{bB}$ & $268.29 \pm 56.53 b B$ & $275.60 \pm 50.84 \mathrm{bB}$ & $335.95 \pm 105.70 \mathrm{aA}$ \\
\hline SS400 & $59.89 \pm 1.13 \mathrm{aA}$ & $122.64 \pm 4.71 \mathrm{aA}$ & $174.28 \pm 4.72 \mathrm{abAB}$ & $189.24 \pm 60.25 \mathrm{abA}$ & $286.31 \pm 12.05 \mathrm{aB}$ & $283.67 \pm 63.85 \mathrm{abA}$ & $336.87 \pm 13.63 \mathrm{aA}$ & $415.15 \pm 59.92 \mathrm{aA}$ \\
\hline SS500 & $58.91 \pm 4.94 \mathrm{aA}$ & $119.85 \pm 4.36 \mathrm{aA}$ & $170.08 \pm 4.86 \mathrm{abA}$ & $219.67 \pm 3.13 \mathrm{aA}$ & $280.54 \pm 9.09 \mathrm{aB}$ & $309.20 \pm 24.65 \mathrm{abA}$ & $326.01 \pm 15.17 \mathrm{aB}$ & $403.01 \pm 40.16 \mathrm{aA}$ \\
\hline SS600 & $52.46 \pm 3.04 \mathrm{bA}$ & $112.12 \pm 5.53 \mathrm{abA}$ & $166.54 \pm 5.72 \mathrm{abA}$ & $206.64 \pm 12.04 \mathrm{aA}$ & $269.24 \pm 8.52 \mathrm{abB}$ & $297.55 \pm 4.66 \mathrm{abB}$ & $311.59 \pm 12.58 \mathrm{aB}$ & $360.29 \pm 65.11 \mathrm{abA}$ \\
\hline SS700 & $58.60 \pm 2.66 \mathrm{aA}$ & $114.34 \pm 4.87 \mathrm{abA}$ & $175.12 \pm 4.35 \mathrm{aA}$ & $223.19 \pm 12.51 \mathrm{aA}$ & $288.44 \pm 11.02 \mathrm{aA}$ & $320.19 \pm 20.91 \mathrm{aA}$ & $327.00 \pm 19.65 \mathrm{aA}$ & $399.19 \pm 12.29 \mathrm{aA}$ \\
\hline
\end{tabular}

Different lower-case letters in the same feedstock within same added $\mathrm{P}$ concentration indicate significant differences among soil and biocharamended soil with different pyrolysis temperatures at $\mathrm{p}<0.05$.

Different uppercase letters in the same pyrolysis temperatures within same added $\mathrm{P}$ concentration indicate significant differences between three types biochar-amended soil at $\mathrm{p}<0.05$.

CC: Corncob; SP: soybean pod; SS: soybean straw; CT: control (i.e., no biochar amendment).

types of biochar amended soils revealed that SP and SS biochar amended soils were apparently more sensitive than CC at pyrolysis temperatures above $500{ }^{\circ} \mathrm{C}$. Higher values of $\mathrm{HI}$ indicate a greater difference in the regularity of adsorptiondesorption process. After biochar amendment, the value of HI was normally lower than CT, which suggests that biochar amendment reduce fixation and increase the utilization of $\mathrm{P}$ fertilizer. However, biochar amendment may also increase the activity of $\mathrm{P}$ in soil and increase the environmental risk of $\mathrm{P}$ (Guan et al., 2013).

\section{DISCUSSION}

\section{Effects of biochar amendment on P adsorption}

The change in soil $\mathrm{P}$ adsorption after biochar amendment was affected by feedstock types, pyrolysis temperature, and their interaction (Table 5); therefore, these differences in $\mathrm{P}$ adsorption may be mainly attributed to differences to biochar properties, such as biochar porosity, surface area, pore size, surface functional groups, and ion-exchange capacity (Sohi et al., 2010; Trazzi et al., 2016). In our study the $\mathrm{Q}_{\mathrm{m}}$ of SP and SS initially increased and then decreased with increasing pyrolysis temperature, because the surface area and total pore volume were significantly increased with increasing pyrolysis temperature up to $400{ }^{\circ} \mathrm{C}$ (Jung et al., 2016). However, trends were reversed at higher pyrolysis temperatures due to the damage of biochar properties. An increase in surface area at high carbonization temperatures is generally attributable to the removal of volatile material, resulting in increased micropore volume (Ahmad et al., 2012). Nonetheless, pores in the biochar were blocked during pyrolysis, which resulted in a decrease in active adsorptive sites that cause softening, melting, and carbonization. Unlike in SP and SS, the $\mathrm{Q}_{\mathrm{m}}$ of CC decreased with increasing pyrolysis temperature (Angin, 2013) because of the different original feedstock properties. The different contents of compositional compounds (including cellulose, hemicelluloses, and lignin) in the original feedstock types (Ahmad et al., 2012) resulted in different pyrolysis temperatures (Mohan et al., 2006), surface area, pores, and functional groups (Sohi et al., 2010). Alternatively, research has indicated that the cation exchange capacity of biochar is markedly higher than its anion exchange capacity (Mukherjee 
Table 4. Parameters of $P$ desorption on black soil and amended black soil using biochar from different feedstocks and pyrolysis temperatures (between 200 and $700{ }^{\circ} \mathrm{C}$ ).

\begin{tabular}{llll}
\hline $\begin{array}{l}\text { Soil } \\
\text { samples }\end{array}$ & \multicolumn{1}{c}{$\mathrm{D}_{\mathrm{m}}$} & \multicolumn{1}{c}{$\mathrm{D}_{\text {avg }}$} & \multicolumn{1}{c}{$\mathrm{HI}$} \\
\hline & \multicolumn{1}{c}{$\mathrm{mg} \mathrm{kg}^{-1}$} & \multicolumn{1}{c}{$\%$} \\
CT & $524.58 \pm 59.22 \mathrm{a}$ & $38.40 \pm 1.35 \mathrm{c}$ & $1.67 \pm 0.10 \mathrm{~b}$ \\
CC200 & $513.89 \pm 27.78 \mathrm{aA}$ & $43.29 \pm 0.60 \mathrm{abB}$ & $1.35 \pm 0.03 \mathrm{deA}$ \\
CC300 & $488.72 \pm 25.07 \mathrm{aA}$ & $41.99 \pm 0.56 \mathrm{aB}$ & $1.44 \pm 0.03 \mathrm{cdA}$ \\
CC400 & $495.85 \pm 36.28 \mathrm{aA}$ & $44.18 \pm 1.65 \mathrm{aB}$ & $1.31 \pm 0.09 \mathrm{eA}$ \\
CC500 & $309.15 \pm 12.67 \mathrm{cB}$ & $36.51 \pm 1.10 \mathrm{~dB}$ & $1.84 \pm 0.08 \mathrm{aA}$ \\
CC600 & $359.56 \pm 6.03 \mathrm{bC}$ & $44.37 \pm 0.97 \mathrm{aB}$ & $1.35 \pm 0.05 \mathrm{deA}$ \\
CC700 & $333.01 \pm 20.29 \mathrm{bcB}$ & $42.50 \pm 0.55 \mathrm{bB}$ & $1.49 \pm 0.13 \mathrm{cA}$ \\
\hline CT & $524.58 \pm 59.22 \mathrm{bc}$ & $38.40 \pm 1.36 \mathrm{c}$ & $1.67 \pm 0.10 \mathrm{a}$ \\
SP200 & $466.17 \pm 22.25 \mathrm{cB}$ & $69.35 \pm 8.32 \mathrm{aA}$ & $0.66 \pm 0.26 \mathrm{~dB}$ \\
SP300 & $513.23 \pm 69.05 \mathrm{bcA}$ & $67.46 \pm 20.21 \mathrm{aA}$ & $0.67 \pm 0.44 \mathrm{~dB}$ \\
SP400 & $563.73 \pm 16.34 \mathrm{bA}$ & $50.97 \pm 2.00 \mathrm{bA}$ & $1.01 \pm 0.07 \mathrm{cB}$ \\
SP500 & $553.08 \pm 60.82 \mathrm{bA}$ & $50.51 \pm 0.96 \mathrm{bcA}$ & $1.03 \pm 0.04 \mathrm{cB}$ \\
SP600 & $638.89 \pm 55.56 \mathrm{aA}$ & $50.98 \pm 1.32 \mathrm{bA}$ & $1.01 \pm 0.05 \mathrm{cB}$ \\
SP700 & $536.07 \pm 13.78 \mathrm{bcA}$ & $43.85 \pm 0.75 \mathrm{bcB}$ & $1.35 \pm 0.02 \mathrm{bB}$ \\
\hline CT & $524.58 \pm 59.22 \mathrm{ab}$ & $38.40 \pm 1.36 \mathrm{~d}$ & $1.67 \pm 0.10 \mathrm{a}$ \\
SS200 & $300.92 \pm 13.61 \mathrm{cC}$ & $42.27 \pm 1.80 \mathrm{cB}$ & $1.47 \pm 0.08 \mathrm{bA}$ \\
SS300 & $455.14 \pm 145.44 \mathrm{bA}$ & $47.86 \pm 1.81 \mathrm{bB}$ & $1.23 \pm 0.15 \mathrm{cdA}$ \\
SS400 & $622.52 \pm 153.13 \mathrm{aA}$ & $49.41 \pm 2.0 \mathrm{abA}$ & $1.12 \pm 0.12 \mathrm{deB}$ \\
SS500 & $571.67 \pm 78.9 \mathrm{abA}$ & $50.14 \pm 1.72 \mathrm{abA}$ & $1.05 \pm 0.07 \mathrm{eB}$ \\
SS600 & $511.11 \pm 114.27 \mathrm{abB}$ & $43.75 \pm 1.26 \mathrm{cB}$ & $1.37 \pm 0.06 \mathrm{bcA}$ \\
SS700 & $558.3 \pm 46.55 \mathrm{abA}$ & $50.84 \pm 2.38 \mathrm{aA}$ & $1.03 \pm 0.07 \mathrm{eC}$ \\
\hline D: & &
\end{tabular}

$\mathrm{D}_{\mathrm{m}}$ : Desorption maximum; $\mathrm{D}_{\text {avg }}$ : average value of desorption ratio; $\mathrm{HI}$ : hysteresis index; CC: corncob; SP: soybean pod; SS: soybean straw; CT: control (i.e., no biochar amendment).

Different lower-case letters in the same biochar feedstock significant differences among soil and biochar-amended soil with different pyrolysis temperatures at $\mathrm{p}<0.05$.

Different uppercase letters in the same pyrolysis temperatures indicate significant differences between three types biochar-amended soil at $\mathrm{p}<0.05$.

Table 5. Changes in $\mathbf{P}$ adsorption and desorption parameters in response to biochar feedstock types and pyrolysis temperatures $(n=72)$.

\begin{tabular}{lccccccc}
\hline Treatment & $\mathrm{Q}_{\mathrm{m}}$ & $\mathrm{K}_{\mathrm{L}}$ & $\mathrm{MBC}$ & $\Delta \mathrm{G}^{\circ}$ & $\mathrm{D}_{\mathrm{m}}$ & $\mathrm{D}_{\text {avg }}$ & $\mathrm{HI}$ \\
\hline Feedstock (F) & 0 & 0.001 & 0 & 0 & 0 & 0 & 0 \\
Pyrolysis temperature (T) & 0 & 0.042 & 0.034 & 0 & 0.008 & 0 & 0.004 \\
$\mathrm{~F} \times \mathrm{T}$ & 0 & 0 & 0 & 0 & 0 & 0 & 0 \\
\hline
\end{tabular}

$\mathrm{Q}_{\mathrm{m}}$ : Langmuir sorption maximum; $\mathrm{K}_{\mathrm{L}}$ : bonding energy constant; $\mathrm{MBC}$ : maximum buffer capacity; $\Delta \mathrm{G}^{\circ}$ : free energy of adsorption; $\mathrm{D}_{\mathrm{m}}$ : desorption maximum; $\mathrm{D}_{\text {avg: }}$ : average value of desorption ratio; HI: hysteresis index. F represents corncob biochar, soybean pod biochar, and soy bean straw biochar.

$\mathrm{T}$ represents pyrolysis temperature range from 200 to $700{ }^{\circ} \mathrm{C}$.

et al., 2011). This finding suggests that the more negative the surface charge of black soil, the lower the adsorption affinity of the soil surface for anions, including phosphate, due to electric repulsion (Jiang et al., 2015).

\section{Effects of biochar amendment on P desorption}

As was seen in P adsorption, the process for desorption of $\mathrm{P}$ in biochar amended soil was influenced by the P concentration in the solution, by feedstock type and pyrolysis temperature (Trazzi et al., 2016). In this study, the P desorption concentration of soil increased with the initial increase in $\mathrm{P}$ concentration. At low initial $\mathrm{P}$ concentrations, sufficient $\mathrm{P}$ adsorption sites on the soil colloid led to a high degree of adsorption. Subsequently, soil colloid adsorptive sites were gradually saturated at higher equilibrium concentrations, which reduced the binding energy, and $\mathrm{P}$ was easily desorbed (Agudelo et al., 2011). The P desorption parameters were sensitive to biochar feedstock type in our study which were consistent with those reported by Hale et al. (2013), who found that cacao shell and CC biochar released significantly different contents 
of $\mathrm{PO}_{4}$-P. In a previous study, original feedstock structure was completely retained, and $\mathrm{C}$ skeleton structure became clearer between 300 and $600{ }^{\circ} \mathrm{C}$ (Hou et al., 2014). However, the effect of biochar feedstock type was offset by increasing pyrolysis temperature, which affected surface properties and $\mathrm{pH}$. In response to rising pyrolysis temperature, and in contrast to aromaticity, the surface acidity and polarity of biochar declined. Phosphate dissociation and soil charge were affected by the $\mathrm{pH}$ value. The $\mathrm{pH}$ increased with rising pyrolysis temperature, which led to decreased $\mathrm{K}_{\mathrm{L}}$ and increased $\mathrm{P}$ desorption. These distinct differences in $\mathrm{P}$ desorption properties present unique possibilities to design biochar for specific soil management objectives (Trazzi et al., 2016).

\section{CONCLUSIONS}

Biochar amendment improved black soil P availability by modulating soil P adsorption and desorption. The feedstock types and pyrolysis temperatures affected $\mathrm{P}$ adsorption and desorption. With increasing temperature, sorption maximum initially increased and then decreased in soybean pod (SP) biochar and soybean straw (SS) biochar amended soils, and declined in corncob (CC) biochar amended soils as pyrolysis temperature increased. The P desorption in SP and SS were higher than that in no biochar amendment (CT) but not in CC. Inflection point of SP and SS at $400{ }^{\circ} \mathrm{C}$ and $\mathrm{CC}$ at $500{ }^{\circ} \mathrm{C}$ were shown in $\mathrm{P}$ adsorption and desorption, which implied that SP and SS at higher than $400{ }^{\circ} \mathrm{C}$ may be the optimum biochar treatment in black soils in Northeast China.

\section{ACKNOWLEDGEMENTS}

This work was supported by Fundamental Research Funds for the Central Universities (under grant Nr 2572016AA35).

\section{REFERENCES}

Agudelo, S.C., Nelson, N.O., Barnes, P.L., Keane, T.D., and Pierzynski, G.M. 2011. Phosphorus adsorption and desorption potential of stream sediments and field soils in agricultural watersheds. Journal of Environmental Quality 40:144-152. doi:10.2134/jeq2010.0153.

Ahmad, M., Lee, S.S., Dou, X., Mohan, D., Sung, J.K., Yang, J.E., et al. 2012. Effects of pyrolysis temperature on soybean stover-and peanut shell-derived biochar properties and TCE adsorption in water. Bioresource Technology 118:536-544. doi:10.1016/j.biortech.2012.05.042.

Angin, D. 2013. Effect of pyrolysis temperature and heating rate on biochar obtained from pyrolysis of safflower seed press cake. Bioresource Technology 128:593-597. doi:10.1016/j.biortech.2012.10.150.

Atkinson, C.J., Fitzgerald, J.D., and Hipps, N.A. 2010. Potential mechanisms for achieving agricultural benefits from biochar application to temperate soils: a review. Plant and Soil 337:1-18. doi:10.1007/s11104-010-0464-5.

China Meteorological Data Service Center. 2018. Available at http://data.cma.cn/site/index.html (accessed April 2018).

Chintala, R., Schumacher, T.E., McDonald, L.M., Clay, D.E., Malo, D.D., Papiernik, S.K., et al. 2014. Phosphorus sorption and availability from biochars and soil/biochar mixtures. CLEAN-Soil, Air, Water 42:626-634. doi:10.1002/clen.201300089.

Cui, H.J., Wang, M.K., Fu, M.L., and Ci, E. 2011. Enhancing phosphorus availability in phosphorus-fertilized zones by reducing phosphate adsorbed on ferrihydrite using rice straw-derived biochar. Journal of Soils and Sediments 11:1135-1141. doi:10.1007/s11368-011-0405-9.

Dari, B., Nair, V.D., Harris, W.G., Nair, P.K.R., Sollenberger, L., and Mylavarapu, R. 2016. Relative influence of soil- vs. biochar properties on soil phosphorus retention. Geoderma 280:82-87. doi:10.1016/j.geoderma.2016.06.018.

Debicka, M., Kocowicz, A., Weber, J., and Jamroz, E. 2016. Organic matter effects on phosphorus sorption in sandy soils. Archives of Agronomy and Soil Science 62:840-855 . doi:10.1080/03650340.2015.1083981.

DeLuca, T.H., Gundale, M.J., MacKenzie, M.D., and Jones, D.L. 2015. Biochar effects on soil nutrient transformations. p. 421 454. In Lehmann, J., and Joseph, S. (eds.) Biochar for environmental management: Science, technology and implementation. Routledge, New York, USA.

Deng, J.C., Jiang, X., Hu, W.P., and Hu, L. 2010. Quantifying hysteresis of atrazine desorption from a sandy loam soil. Journal of Environmental Sciences 22:1923-1929. doi:10.1016/S1001-0742(09)60340-5. 
Guan, L.Z., Chan, Z.X., Zhang, J.H., Zhang, G.C., and Zhang, Y. 2013. Influence of carbonized maize stalks on fractions and availability of phosphorus in brown soil. Scientia Agricultura Sinica 46:2050-2057. doi:10.3864/j.issn.0578-1752.2013.10.010.

Gul, S., and Whalen, J.K. 2016. Biochemical cycling of nitrogen and phosphorus in biochar-amended soils. Soil Biology and Biochemistry 103:1-15. doi:10.1016/j.soilbio.2016.08.001.

Hale, S.E., Alling, V., Martinsen, V., Mulder, J., Breedveld, G.D., and Cornelissen, G. 2013. The sorption and desorption of phosphate-P, ammonium-N and nitrate-N in cacao shell and corn cob biochars. Chemosphere 91:1612-1619. doi:10.1016/j.chemosphere.2012.12.057.

Hou, J.W., Suo, Q.Y., Liang, H., Han, X.Q., and Liu, C.S. 2014. Effects of carbonization temperature on Artemisia ordosica biochar morphology and chemical properties. Soils 46:814-818. doi:10.13758/j.cnki.tr.2014.05.007.

Jiang, J., Yuan, M., Xu, R.K., and Bish, D.L. 2015. Mobilization of phosphate in variable-charge soils amended with biochars derived from crop straws. Soil and Tillage Research 146:139-147. doi:10.1016/j.still.2014.10.009.

Jung, K.W., Kim, K., Jeong, T.U., and Ahn, K.H. 2016. Influence of pyrolysis temperature on characteristics and phosphate adsorption capability of biochar derived from waste-marine macroalgae (Undaria pinnatifida roots). Bioresource Technology 200:1024-1028. doi:10.1016/j.biortech.2015.10.016.

Kang, R.F., Ren, Y., Wu. H.J., and Zhang, S.X. 2016. Changes in the nutrients and fertility of black soil over 26 years in Northeast China. Scientia Agricultura Sinica 49:2113-2125. doi:10.3864/j.issn.0578-1752.2016.11.008.

Kravchenko, Y.S., Zhang, X., Liu, X., Song, C., and Cruse, R.M. 2011. Mollisols properties and changes in Ukraine and China. Chinese Geographical Science 21(3):257-266. doi:10.1007/s11769-011-0467-z.

Kumar, A.S.K., Kakan, S.S., and Rajesh, N. 2013. A novel amine impregnated graphene oxide adsorbent for the removal of hexavalent chromium. Chemical Engineering Journal 230:328-337. doi:10.1016/j.cej.2013.06.089.

Lair, G.J., Zehetner, F., Khan, Z.H., and Gerzabek, M.H. 2009. Phosphorus sorption-desorption in alluvial soils of a young weathering sequence at the Danube River. Geoderma 149:39-44. doi:10.1016/j.geoderma.2008.11.011.

Lehmann, J., Rillig, M.C., Thies, J., Masiello, C.A., Hockaday, W.C., and Crowley, D. 2011. Biochar effects on soil biota-a review. Soil Biology and Biochemistry 43:1812-1836. doi:10.1016/j.soilbio.2011.04.022.

Liu, X., Lee Burras, C., Kravchenko, Y.S., Duran, A., Huffman, T., Morras, H., et al. 2012. Overview of Mollisols in the world: distribution, land use and management. Canadian Journal of Soil Science 92(3):383-402. doi:10.4141/cjss2010-058.

Lu, R.K. 1999. Analytical methods of soil agrochemistry. Chinese Agriculture Science and Technology, Beijing, China .

Mohan, D., Pittman, C.U., and Steele, P.H. 2006. Pyrolysis of wood/biomass for bio-oil: a critical review. Energy and Fuels 20:848-889. doi:10.1021/ef0502397.

Mukherjee, A., Zimmerman, A.R., and Harris, W. 2011. Surface chemistry variations among a series of laboratory-produced biochars. Geoderma 163:247-255. doi:10.1016/j.geoderma.2011.04.021.

Parvage, M.M., Ulén, B., Eriksson, J., Strock, J., and Kirchmann, H. 2013. Phosphorus availability in soils amended with wheat residue char. Biology and Fertility of Soils 49:245-250. doi:10.1007/s00374-012-0746-6.

Shen, J., Yuan, L., Zhang, J., Li, H., Bai, Z., Chen, X., et al. 2011. Phosphorus dynamics: from soil to plant. Plant Physiology 156:997-1005. doi:10.1104/pp.111.175232.

Shi, C., Zhang, P.Y., Guo, J.B., and Zhang, G.M. 2016. Phosphorus adsorption performance onto sewage sludge biochar. Chinese Journal of Environmental Engineering 10:3187-3193. doi:10.12030/j.cjee.201508021.

Sohi, S.P., Krull, E., Lopez-Capel, E., and Bol, R. 2010. A review of biochar and its use and function in soil. p. 47-82. In Sparks, D.L. (ed.) Advances in Agronomy. Academic Press, Burlington, Massachusetts, USA.

Spokas, K.A., Cantrell, K.B., Novak, J.M., Archer, D.W., Ippolito, J.A., Collins, H.P., et al. 2012. Biochar: a synthesis of its agronomic impact beyond carbon sequestration. Journal of Environmental Quality 41:973-989. doi:10.2134/jeq2011.0069.

Sun, F.F., and Lu, S.G. 2014. Biochars improve aggregate stability, water retention, and pore-space properties of clayey soil. Journal of Plant Nutrition and Soil Science 177:26-33. doi:10.1002/jpln.201200639.

Trazzi, P.A., Leahy, J.J., Hayes, M.H.B., and Kwapinski, W. 2016. Adsorption and desorption of phosphate on biochars. Journal of Environmental Chemical Engineering 4:37-46. doi:10.1016/j.jece.2015.11.005.

Wang, G.P., Liu, J.S.,Zhao, H.Y., Wang, J.D., and Yu, J.B. 2007. Phosphorus sorption by freeze-thaw treated wetland soils derived from a winter-cold zone (Sanjiang Plain, Northeast China). Geoderma 138:153-161. doi:10.1016/j.geoderma.2006.11.006.

Xu, G., Sun, J.N., Shao, H.B., and Chang, SX. 2014. Biochar had effects on phosphorus sorption and desorption in three soils with differing acidity. Ecological Engineering 62:54-60. doi:10.1016/j.ecoleng.2013.10.027.

Yang, X.Y., Fan, R.Y., Wang, E.H., Xia, X.Y., and Chen, X.W. 2014. Vertical variation of phosphorus sorption and desorption properties in undisturbed black soil of Northeast China. Chinese Journal of Soil Science 47:378-383. doi:10.19336/j.cnki.trtb.2014.06.029. 
Yao, Q., Liu, J.J., Yu, Z.H., Li, Y.S., Jin, J., Liu, X.B., et al. 2017. Three years of biochar amendment alters soil physiochemical properties and fungal community composition in a black soil of northeast China. Soil Biology and Biochemistry 110:56-67. doi:10.1016/j.soilbio.2017.03.005.

Zhang, L., Hong, S., He, J., Gan, F.X., and Ho, Y.S. 2011. Adsorption characteristic studies of phosphorus onto laterite. Desalination and Water Treatment 25:98-105. doi:10.5004/dwt.2011.1871.

Zhang, Y., Price, G.W., Jamieson, R., Burton, D., and Khosravi, K. 2017. Sorption and desorption of selected non-steroidal anti-inflammatory drugs in an agricultural loam-textured soil. Chemosphere 174:628-637. doi:10.1016/j.chemosphere.2017.02.027.

Zhao, P., Li, S., Wang, E., Chen, X., Deng, J., and Zhao, Y. 2018. Tillage erosion and its effect on spatial variations of soil organic carbon in the black soil region of China. Soil and Tillage Research 178:72-81. doi:10.1016/j.still.2017.12.022.

Zhou, Y., Berruti, F., Greenhalf, C., and Henry, H.A. 2017. Combined effects of biochar amendment, leguminous cover crop addition and snow removal on nitrogen leaching losses and nitrogen retention over winter and subsequent yield of a test crop (Eruca sativa L.) Soil Biology and Biochemistry 114:220-228. doi:10.1016/j.soilbio.2017.07.023.

Zwetsloot, M.J., Lehmann, J., and Solomon, D. 2015. Recycling slaughterhouse waste into fertilizer: how do pyrolysis temperature and biomass additions affect phosphorus availability and chemistry? Journal of the Science of Food and Agriculture 95:281-288. doi:10.1002/jsfa.6716. 